\title{
A!
}

This is an electronic reprint of the original article.

This reprint may differ from the original in pagination and typographic detail.

Helin, Kristo; Jääskeläinen, Jaakko; Syri, Sanna

\section{Energy security impacts of decreasing CHP capacity in Finland}

Published in:

15th International Conference on the European Energy Market, EEM 2018

DOI:

10.1109/EEM.2018.8469786

Published: 20/09/2018

Document Version

Peer reviewed version

Please cite the original version:

Helin, K., Jääskeläinen, J., \& Syri, S. (2018). Energy security impacts of decreasing CHP capacity in Finland. In 15th International Conference on the European Energy Market, EEM 2018 (Vol. 2018-June). [8469786]

(International Conference on the European Energy Market). IEEE. https://doi.org/10.1109/EEM.2018.8469786

This material is protected by copyright and other intellectual property rights, and duplication or sale of all or part of any of the repository collections is not permitted, except that material may be duplicated by you for your research use or educational purposes in electronic or print form. You must obtain permission for any other use. Electronic or print copies may not be offered, whether for sale or otherwise to anyone who is not an authorised user. 


\title{
Energy Security Impacts of Decreasing CHP Capacity in Finland
}

\author{
Kristo Helin, Jaakko Jääskeläinen, Sanna Syri \\ Department of Mechanical Engineering \\ School of Engineering, Aalto University \\ Espoo, Finland \\ kristo.helin@aalto.fi
}

\begin{abstract}
Finland, as part of the Nordic electricity market, is experiencing an era of low electricity market prices. This has practically removed all condensing power capacity from the electricity market. The Finnish combined heat and power (CHP) capacity is facing a similar trend. Some industry experts argue that the described trend could induce serious energy security issues. In this paper, we analyse a scenario where the average electricity spot price remains under $30 € / M W h$ throughout the $2020 \mathrm{~s}$ and energy use of coal is phased out by 2030 , resulting in a notable decrease in CHP capacity. We assess the energy security implications in the scenario on a national and multi-national level. Additionally, we present a case study of Helsinki to give examples of the identified energy security issues on a city level. The results provide policy makers insight in decision making regarding the operating environment of $\mathrm{CHP}$ production in Finland.
\end{abstract}

Index Terms - cogeneration, energy resources, energy security, power generation, sustainable development

\section{INTRODUCTION}

Electricity production in Finland is undergoing a technology shift. Thermal production has been on a clear decrease for over a decade [1]. This includes both condensing power and combined heat and power (CHP) production. The last condensing power plant has practically left the electricity spot market, and there is an ongoing trend to replace ageing fossil CHP plants with heat-only boilers (HOBs) [2]. These changes can be attributed to the prolonged lower-thanexpected electricity demand and market price [3]. Additionally, a political decision has been made to phase out coal in normal energy use in Finland by 2030 [4].

The yearly average market price of electricity in Finland has been 30-33 €/MWh since 2015. The Finnish government expects the price to increase by 2030 [4], as do many other institutions, e.g. [5], [6]. The expected increases are mostly attributed to increases in fuel prices, $\mathrm{CO}_{2}$ emission price, and electricity demand. However, the increases can be questioned, and in this paper we focus on the scenario where the market price does not increase. The resulting decrease in CHP capacity may be expected at some point in the future in any case, and the discussion of the possible consequences is therefore relevant.

The bulk of electricity production in Finland is distributed between nuclear (34\% in 2016), hydro (24\%), and CHP (32\%) [1]. Net imports cover $22 \%$ of the electricity demand. Of total CHP production, about $60 \%$ is categorised as district heat $(\mathrm{DH})$ producing, and the rest as industrial. Half of Finns live in $\mathrm{DH}$ heated buildings, and for the five largest cities combined the corresponding share is $80 \%$ [7].

Finland has a high per capita energy consumption due to its cold climate and high industrial consumption. Consequently, both security of supply and energy security in general have been high in the political agenda. Traditionally, CHP has played an important role in heat and electricity production, which is why discussion about its future is very much present among industry experts and politicians. Currently, the consensus is that a significant reduction in the Finnish CHP capacity would have detrimental energy security implications. However, public discussion on the matter so far lacks both clarity of the implications of the CHP capacity decrease, and concrete potential strategies to prevent the decrease, should it be deemed necessary.

This paper reviews the possible scenario of a significant reduction in the Finnish CHP capacity. The paper introduces relevant dimensions of energy security and analyses the system-level implications of the scenario. We study a scenario where coal is successfully phased out in energy use in Finland by 2030 , and the electricity market price remains below $30 € / \mathrm{MWh}$ due to the deployment of two new nuclear power plants and transmission lines between Finland and Sweden. The low electricity price level throughout the 2020s discourages market-based investment in power production. Moreover, no new energy policy measures are implemented in addition to those presented in the new National Energy and Climate Strategy in late 2016 [4].

This paper is organised as follows. First, section II discusses the dimensions of energy security that are relevant in this context. Section III presents a case study of Helsinki to analyse the quantitative consequences of replacing retiring 
CHP capacity with heat-only boilers. Section IV discusses the nation-wide and multi-national energy security impacts caused by the decreasing CHP capacity and, finally, section V draws conclusions.

\section{RELEVANT DIMENSIONS OF ENERGY SECURITY}

Energy security is a complex and multidimensional concept. The dimensions range from the sustainability and environmental impacts of energy production to the security of supply and energy system costs [8]. No academic consensus has been reached in the definitions or indicators that should be used for political decision-making [9]. As one important authority, the International Energy Association defines energy security as the uninterrupted availability of energy sources at an affordable price [10]. A common framework for energy security is the so-called 4 A's: Availability, Affordability, Acceptability and Accessibility.

The relative importance of the features of energy security differ by perspective. For example, nations and corporations maintain different sets of priorities. Moreover, apart from energy efficiency, measures to improve energy security typically involve trade-offs. For example, increasing system reliability tends to increase system costs. Perspective differences need to be considered also in this paper. In essence, we need to categorise the energy security implications of the discussed decrease in CHP heat and electricity production. We choose to discuss three levels from local to multi-national: Helsinki (a single DH network), Finland (a country), and the wider North European energy market (several countries).

The city-level analysis assumes that the same entity owns all infrastructure and production facilities and hence heat and power procurement are optimised on a system level. Thus, the most relevant energy security issues are the system costs (required operational and capital expenditures), $\mathrm{CO}_{2}$ emissions, and security of supply. On a national level, issues such as self-sufficiency, competitiveness, generation adequacy and $\mathrm{CO}_{2}$ emissions are the most relevant. On the multinational level, the analysis concentrates on the causal implications that trends in the Finnish energy sector have on energy production elsewhere in Northern Europe.

\section{CASE HELSINKI}

The analysed scenario has several relevant energy security implications on the city-level. They are especially visible in the capital of Finland, Helsinki, which is currently reliant on natural gas and coal CHP. We assess the changes in the energy security of the city due to the assumed changes, which call for sizeable investment in heat production in the city before 2030.

\section{A. Current capacities}

The heating capacities in Helsinki in 2016 and 2030 are described in Table I. The 2030 values are the base mix that we use in our modelling (they alone are not adequate for needed production, as described later on). The 2030 values for the capacities of coal and natural gas follow from reasoning presented earlier in this paper, while changes in the capacities of biomass, heat pumps and heavy fuel oil are based on existing decisions.

Table I. Heating capacity mix in Helsinki in 2016 and 2030.

\begin{tabular}{|l|c|c|c|c|}
\hline Fuel & \multicolumn{2}{|c|}{ Heating capacity in 2016 } & \multicolumn{2}{c|}{$\begin{array}{c}\text { Heating capacity in } \\
\mathbf{2 0 3 0}\end{array}$} \\
\hline & HOB & CHP & HOB & CHP \\
\hline Natural gas & 912 & 587 & 912 & 0 \\
\hline Coal & 190 & 729 & 0 & 0 \\
\hline Heavy fuel oil & 873 & - & 865 & - \\
\hline Light fuel oil & 136 & - & 136 & - \\
\hline Heat pump & 90 & - & 112 & - \\
\hline Biomass & 0 & - & 92 & - \\
\hline
\end{tabular}

\section{B. Fuel alternatives}

In accordance with the Finnish Energy and Climate Strategy, Helsinki aims to decarbonise its energy sector in the long run. Thus, we expect any new plants to utilise biomass (wood chips, wood pellets, etc.), heat pumps or geothermal heat. Additionally, natural gas is a potential alternative due to existing pipelines and wide current use. Because heat pumps and geothermal heat have high locational requirements, we limit our assessment to the options of biomass and natural gas. We assume the biomass to be wood pellets. This is because the availability of forest fuels is limited in the capital region [11], and other alternatives similar to wood pellets have smaller established markets. Wood pellets allow long transport distances [12] and have a ready European-Russian market [13] with trade connections with Finland [14].

\section{Modelling method}

We make a simple, myopic model of $\mathrm{DH}$ production in Helsinki. The model is a Python program written for this work. It goes through a year hour-by-hour with a set of heating plants and a fixed heat demand profile. Demand is met for each hour separately with the lowest possible variable costs. Variable costs include current cost levels for operation and maintenance, taxes, emission prices, etc., and a future estimate for fuel prices. Heating plant utilisation is only constrained by the plants' maximum capacities, i.e. no ramping rates are considered. To analyse the future heating system, we run the model repeatedly with two additional HOBs with different fuels that are sized for each model run separately. All size combinations are tested with $100 \mathrm{MW}$ increments up to a total capacity that is sufficient for interpretation of the results.

\section{New capacity assessment}

We use the described model to study the addition of natural gas and wood pellet HOBs to the 2030 base capacity mix presented in Table I. We use the heating profile (estimate) of 2016, the electricity price of $30 € / \mathrm{MWh}$, emission price of $30 € / \mathrm{tCO}_{2}$, and fuel prices from [15], except for wood pellets $(149 € / \mathrm{t})$.

The model results are shown in Figure 1. The capacities of wood pellet and natural gas heat production are shown for 2016 and 2030 (base mix). The coloured area depicts potential combinations of adding new capacity with the two fuels. The colour gradient shows the estimated total cost of 
operating costs (including fuel, fuel tax etc.) for all plants plus the investment costs for new plants. The black sloped lines indicate the capacity combinations that are required for i) adequate capacity for production, ii) the $\mathrm{N}-1$ criterion, and iii) production without oil in normal use. The horizontal short lines indicate different levels of wood pellet consumption, namely i) Finnish pellet production in 2015 (0.3 Mt) [14], ii) Finnish potential for pellet production as estimated in 2012 (max. 0.6 Mt) [14], and iii) a 2006 vision of Finnish pellet production in $2020(1 \mathrm{Mt})$ [16].

As is shown in Figure 1, some additional investments are necessary before 2030 . The results show wood pellets as the cheaper alternative of the two discussed options (due to no emission costs), with the lowest total cost at about $1500 \mathrm{MW}$ of pellets and no additional natural gas. The wood pellet consumption is very high compared to the domestic production in 2015 (red line in the figure).

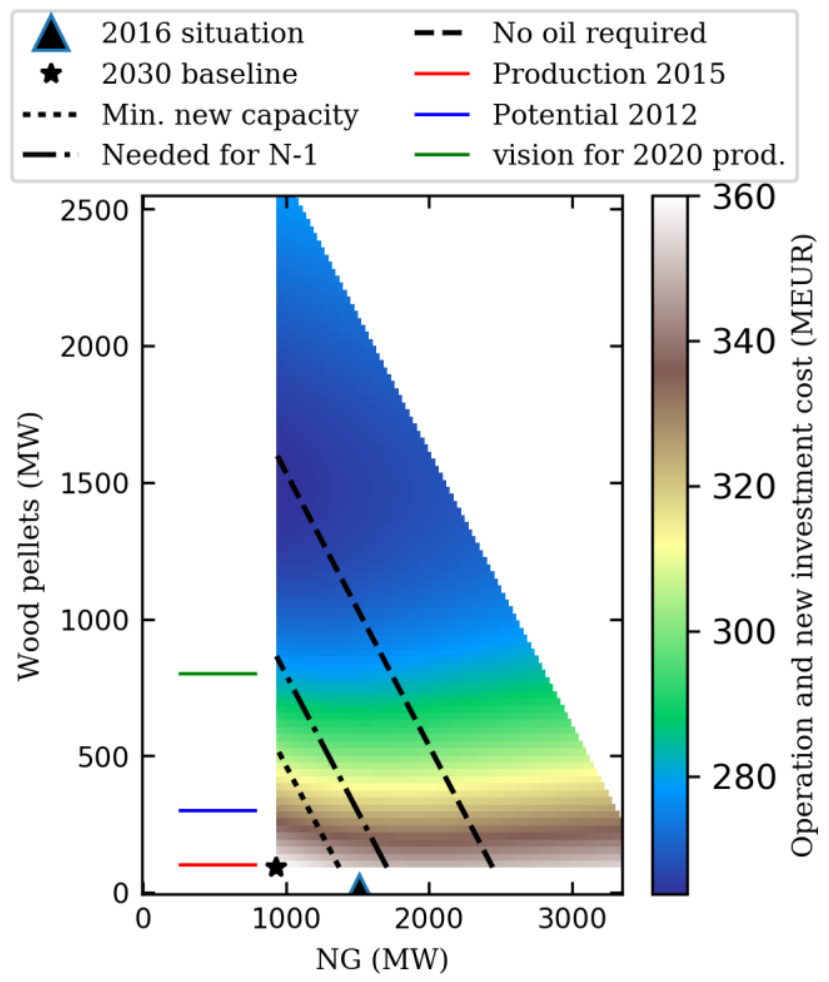

Figure 1. Heating capacity increase options for Helsinki for 2030.

\section{E. Energy security implications}

The results indicate at least a partial fuel shift towards wood pellets (in addition to the assumed shift from CHP plants to HOBs). This will lead to lower costs and lower (calculated) emissions from heat production compared to natural gas. The energy security implications of this scenario are categorised and briefly analysed next:

- Fuel availability: As wood pellets deteriorate when stored outdoors [17] and require a large storage space, the stored fuel amounts at heating plants will be measured in days [18]. Additionally, the production of pellets is interlinked with other commercial activities (e.g. wood product manufacturing), which may change the availability of pellets during the cycles of the economy. Due to these issues, plants will need to make arrangements to secure the price and availability of pellets in the long term. On the other hand, the wood pellet market is less tied to one producer than that of natural gas, even though most imports for both currently come from Russia [14], [19].

- Crisis vulnerability: Due to the reasons described above, back-up fuel will most likely need to be different from the main fuel. This is important in case reliable transport connections are jeopardised.

- Economic issues: Finnish taxation favours heat production in CHP plants over HOB plants even without simultaneous electricity production [15]. Thus, a switch to the latter will increase the share of tax in the cost of DH production. The market price of wood pellets may also be affected by the fast development of the European pellet market.

- $\mathrm{CO}_{2}$ emissions: Wood pellet use is considered carbonneutral due to the recapture of $\mathrm{CO}_{2}$ by a sufficient net growth of carbon stock [20]. This net growth may be endangered in some areas if the global market becomes very large. Additionally, transport type, transport distance and the manufacturing process of the pellets have significant impacts on the actual emissions of wood pellet utilisation.

- Social acceptability: CHP heat production is regarded in Finland as environmentally friendly utilisation of waste heat from efficient electricity production (which is not incorrect). The switch to HOBs may change this reputation and worsen the acceptability of $\mathrm{DH}$. On the other hand, increases in bioenergy, CHP or not, would reflect well on the social acceptability of $\mathrm{DH}$ in Helsinki. Local policymakers have long worked to increase the share of biomass in heat production.

\section{NATIONAL AND INTERNATIONAL IMPLICATIONS OF DECREASING CHP CAPACITY IN FINLAND}

In this section, we analyse the main implications of the CHP capacity decrease in Finland on a national level, and in North Europe on a multi-national level. The main concerns revolve around generation adequacy, flexibility, inertia, and self-sufficiency, which are categorised and discussed in the following subsections.

\section{A. Generation adequacy}

Generation adequacy in Finland has been a topical issue ever since the record-high electricity demand peak in early 2016 [21]. However, despite ENTSO-E's cautionary adequacy forecast in late 2017 [22], several studies and reports indicate that issues regarding generation adequacy are improbable in the coming years, and even more so after the presumed deployment of Olkiluoto 3 nuclear power plant (OL3) in 2019 [21], [23], [24]. Moreover, a recent study [25] analysed the development of generation adequacy in Finland according to the scenarios of the new National Energy and Climate Strategy [4]. The study concluded that generation adequacy 
should in fact improve by 2030, despite accounting for a significant reduction in CHP capacity. This is mainly due to new nuclear power capacity and increased transmission capacity between Finland and Sweden. The study estimates that there should be over $2800 \mathrm{MW}$ of available capacity left after supplying the demand during an extreme winter demand peak in 2030 .

\section{B. Flexibility and inertia}

Currently, there are no clear price signals in the Finnish electricity market indicating a lack of flexibility. Price spikes are rare enough not to encourage investment in peak power production. On the contrary, practically all condensing power capacity (which is typically used for peak power production) in Finland has been decommissioned, mothballed or allocated to strategic reserves during the 2000s. The significant amount of hydropower production in the Nordics has so far balanced supply and demand well, and flexibility has not been a real issue. In the future, however, the development of the need for flexibility may warrant attention. This is due to the decreasing amount of flexible thermal production (i.e. CHP), the increasing share of variable renewable production in the Nordics and in Europe, and the increasing transmission capacity between the Nordics and Central Europe and UK. Implications of the latest are a subject of future research: On one hand, the increasing transmission capacity allows Nordic countries the access to Central European thermal production during the demand peaks. On the other hand, the cross-border transmission lines will increase the demand for the cheap and flexible Nordic hydropower.

The implications of decreasing CHP capacity on inertia, i.e. the amount of kinetic energy in the power system, have also raised concerns. However, should the two new nuclear power plants in Finland be deployed, their rotating mass should compensate for the decreasing thermal capacity in Finland [26]. As the European power markets integrate, the inertia issue is more and more affected by what happens outside the national borders. Therefore, also the development of inertia in the system warrants attention in the future.

\section{Self-sufficiency}

Self-sufficiency in power production is a two-sided issue. One side is the self-sufficiency regarding capacity, i.e. generation adequacy, which we discussed earlier. The other side is self-sufficiency regarding primary energy supply. Despite the increasing self-sufficiency, Finland still imports almost two thirds of its primary energy (64\% in 2014 [27]). The CHP capacity that is decommissioned or mothballed in our scenario is mainly based on coal and natural gas. Finland imports $100 \%$ of its coal and natural gas and hence the decommissioning would not increase Finnish primary energy imports. Actually, due to the treatment of imported electricity as a primary energy source, decreasing coal and natural gas electricity production would technically decrease the primary energy imports of Finland.

\section{Implications on the multi-national energy system}

Demand for electricity is fairly inelastic both in Finland and on the European level, and it is hence not greatly affected by the Finnish CHP production or the lack thereof. Additionally, a large share of Nordic electricity production has low marginal costs (e.g. hydro, wind, nuclear). This means that these technologies are typically already prioritised in the market. Therefore, without additional investment in power capacity, a decrease in Finnish CHP production would not be replaced with any of the above-mentioned technologies, and it would not decrease electricity demand either. Instead, electricity would be imported from countries that have available thermal power production capacity. This view is corroborated by past experiences: In the 2000s, production "losses" (due to outages in Swedish nuclear power units and low hydropower production) have eventually been compensated by increases in thermal production in inter alia Finland and Denmark [28], [29]. However, as thermal power capacities in Finland decrease in our scenario (probably along with Denmark), the compensating production will eventually take place in other countries, such as Germany, the Baltics or Poland. These countries have condensing power capacity with a capacity factor well below $100 \%$ and hence potential to increase production. Therefore, as long as CHP production in Finland eventually replaces separate heat and power productions that both utilise fossil fuels, CHP production is clearly the more environmentally friendly option. This means that a decrease in the Finnish CHP capacity has the potential to increase fossil fuel use and carbon emissions in the North European level. The net effect on nearby countries should not be ignored when discussing energy security, especially when it comes to sustainability and acceptability issues.

\section{CONCLUDING DISCUSSION}

In this work we have identified and assessed the energy security issues arising in Finland in a scenario where the energy use of coal is ended, and the electricity market price remains below $30 € / \mathrm{MWh}$ throughout the $2020 \mathrm{~s}$. This results in a sharp decrease in CHP capacity and a notable shift in fuel consumption in Finland. We have assessed the energy security implications on three levels: local, national, and multinational.

On the local level, we assessed future options for the DH production in Helsinki. We estimated that heat production would shift primarily towards biomass HOBs, and secondarily to natural gas HOBs. The energy security implications would be mostly related to the fuel shift to wood pellets. High wood pellet consumption includes sizeable energy security risks due to the fast growing global market and low storability. The risks are due to uncertainties in e.g. actual $\mathrm{CO}_{2}$ emissions, costs, availability, and dependence on economic cycles. Other implications of the switch to HOBs (from CHP base production) are related to the social acceptance and cost level of DH.

On a national level, the main concerns revolve around generation adequacy, flexibility, inertia and self-sufficiency. Our analysis shows that none of the above-mentioned are clearly jeopardised. The prolonged low electricity market price is a signal of over-supply in the market. However, the current Finnish energy policy is leading to an even improved generation adequacy despite the price signals. Moreover, there are no price signals indicating a flexibility scarcity, and the inertia of the planned new nuclear power plants should 
compensate for the reduction in CHP capacity. However, flexibility and inertia are complex issues that warrant attention in the future with the integrating power markets. The CHP capacity under possible decommissioning is mainly based on burning coal or natural gas. Therefore, the decreasing capacity will not weaken the Finnish self-sufficiency in energy supply either. All implications mentioned on the local level are present on the national level as well.

The multi-national energy security implications in our analysis are perhaps the most tangible. Due to the inelastic demand for electricity, changes in Finnish electricity production will eventually be compensated for by a change in production in the wider, multi-national electricity market. Since all carbon-neutral production is already prioritised in the merit order due to their low marginal costs (excluding biomass), the Finnish CHP production likely "replaces" coalbased condensing power production in e.g. Poland, Germany or the Baltics. Evidently, as long as CHP production is an alternative to separate heat and power production, it has notable positive energy security impacts regarding energy efficiency and $\mathrm{CO}_{2}$ emissions.

All in all, the markets are currently not giving signals that DH CHP production is competitive enough in the Finnish energy market - despite its thermodynamic efficiency and long history in Finland. Therefore, if the price of electricity remains as low as in our scenario, it is up for the politicians to decide whether its positive impact on the Finnish economy and on the environment in the multi-national scope are compelling enough reasons to subsidise CHP production.

\section{ACKNOWLEDGMENT}

This research was supported by the Strategic Research Council's Winland Project (No.303628).

\section{REFERENCES}

[1] Official Statistics of Finland (OSF), "Production of electricity and heat," $2017 . \quad$ [Online]. Available: http://www.stat.fi/til/salatuo/index_en.html. [Accessed: 01-Mar-2018].

[2] Tekniikka \& talous, "Kivihiilikielto käynnistäisi tappelun biomassasta (Coal ban would start a fight for biomass). News article.," Nov. 2016.

[3] Nord pool, "Day-ahead prices," Nord pool, 2017.

[4] Ministry of Economic Affairs and Employment, "Government report on the National Energy and Climate Strategy for 2030," 2017. [Online].

Available: tem.fi/documents/1410877/2769658/Government+report+on+the+Nati onal+Energy+and+Climate+Strategy+for $+2030 / 0 b b 2 a 7 b e-d 3 c 2-4149-$ a4c2-78449ceb1976. [Accessed: 20-Dec-2017].

[5] Statnett, Long-term market analysis - The nordic region and europe 2016-2040. 2016.

[6] International Energy Agency, Nordic energy technology perspectives 2016. IEA Publications, 2016.

[7] Finnish Energy, "Kaukolämpötilasto 2016 [District heat statistic 2016]," 2016.

[8] B. W. Ang, W. L. Choong, and T. S. Ng, "Energy security: Definitions, dimensions and indexes," Renewable and Sustainable Energy Reviews, vol. 42, pp. 1077-1093, Feb. 2015.

[9] C. Böhringer and M. Bortolamedi, "Sense and no(n)-sense of energy security indicators," Ecological Economics, vol. 119, no. Supplement C, pp. 359-371, Nov. 2015.

[10] International Energy Agency, "Energy security.” [Online]. Available: https://www.iea.org/topics/energysecurity/. [Accessed: 09-Mar-2018].
[11] Finnish forest research institute (Metla), "Metsähakkeen alueellinen korjuupotentiaali ja käyttö vuonna 2020 [The regional harvesting potential and use of forest chips in the year 2020]," Nov. 2014.

[12] VTT, "Metsähakkeen hankinta- ja toimituslogistiikan haasteet ja kehittämistarpeet [Challenges and development needs of the procurement and delivery logistics of forest chips]," Espoo, 2010.

[13] B. Mola-Yudego, M. Selkimäki, and J. R. González-Olabarria, "Spatial analysis of the wood pellet production for energy in Europe," Renewable Energy, vol. 63, pp. 76-83, Mar. 2014.

[14] S. Proskurina, E. Alakangas, J. Heinimö, M. Mikkilä, and E. Vakkilainen, "A survey analysis of the wood pellet industry in Finland: Future perspectives," Energy, vol. 118, pp. 692-704, Jan. 2017.

[15] VTT, "Yhdistetyn sähkön- ja lämmöntuotannon hiilidioksidiveron puolituksen poiston vaikutukset [Effects of removal of the halving of the carbon dioxide tax of combined heat and power production]," Mar. 2016.

[16] Finnish forest research institute (Metla), "Suomen metsiin perustuva hyvinvointi 2015: Katsaus Suomen metsäalan kehitykseen ja tulevaisuuden vaihtoehtoihin [Finnish forest based wellbeing 2015: A look into the future options and development of the Finnish forest industry]," 2006.

[17] S. Graham, C. Eastwick, C. Snape, and W. Quick, "Mechanical degradation of biomass wood pellets during long term stockpile storage," Fuel Processing Technology, vol. 160, pp. 143-151, Jun. 2017.

[18] Ramboll Finland Oy, "Helen Oy: Tattarisuon lämpökeskuksen ympäristövaikutusten arviointiohjelma [Environmental impact assessment programme of the Tattarisuo heating plant]," 1510037706.

[19] Official Statistics of Finland (OSF), "Energy supply and consumption," 2017. [Online]. Available: http://www.stat.fi/til/ehk/index_en.html. [Accessed: 01-Mar-2018].

[20] M. den Herder, M. Kolström, M. Lindner, T. Suominen, D. Tuomasjukka, and M. Pekkanen, "Sustainability impact assessment on the production and use of different wood and fossil fuels employed for energy production in North Karelia, Finland," Energies, vol. 5, no. 11, 2012.

[21] J. Jääskeläinen, B. Zakeri, and S. Syri, "Adequacy of Power Capacity during Winter Peaks in Finland," in 2017 14th International Conference on the European Energy Market (EEM), 2017, pp. 1-6.

[22] ENTSO-E, "Mid-term Adequacy Forecast 2017," 2017. [Online]. Available:

www.entsoe.eu/Documents/SDC\%20documents/MAF/MAF_2017_rep ort_for_consultation.pdf. [Accessed: 11-Dec-2017].

[23] J. Jääskeläinen and K. Huhta, "Trouble Ahead? An Interdisciplinary Analysis of Generation Adequacy in the Finnish Electricity Market," International Energy Law Review, vol. 8, Dec. 2017.

[24] Pöyry Management Consulting, "Selvitystyö tarvittavasta tehoreservin määästä ajanjaksolle 2017-2022 ('An assessment of the required peak load reserves for 2017-2022')," 20-Dec-2017. [Online]. Available: www.energiavirasto.fi/documents/10191/0/EV_Tehoreservin+määrä 2017-2022_Loppuraportti.pdf/8eca5950-0b8f-429e-a27e23f77cae5da4. [Accessed: 20-Dec-2017].

[25] J. Jääskeläinen, N. Veijalainen, S. Syri, M. Marttunen, and B. Zakeri, "Energy security impacts of a severe drought on the future Finnish energy system," Journal of Environmental Management, SDEWES2017 Special Issue, in press.

[26] ENTSO-E, "Future system inertia," 2015.

[27] Finnish Ministry of Economic Affairs and Employment, Taustaraportti kansalliselle energia-ja ilmastostrategialle vuoteen 2030 (Background report for the national energy and climate strategy until year 2030). 2017.

[28] NordREG, "Nordic market report 2007 - Developments in the Nordic electricity market," $2007 . \quad$ [Online]. Available: www.nordicenergyregulators.org/wp-content/uploads/2013/02/marketreport-2007.pdf. [Accessed: 13-Dec-2017].

[29] NordREG, "Nordic market report 2011 - Development in the Nordic electricity market," 2011. [Online]. Available: www.nordicenergyregulators.org/wpcontent/uploads/2013/02/nmr2011-final-for-publication.pdf. [Accessed: 13-Dec-2017]. 